\author{
Editorial: Poetic Inquiry in/for/as \\ John J. Guiney Yallop, Acadia University \\ Sean Wiebe, University of Prince Edward Island \\ Sandra L. Faulkner, Bowling Green State University
}

\begin{abstract}
An editorial written by the Guest Editors for a special issue of in education on the practices of poetic inquiry.
\end{abstract}




\title{
Editorial: Poetic Inquiry in/for/as
}

We open with four haiku, which capture our conversations about content and process during our collaboration as guest editors for this in education special issue on poetic inquiry.

\author{
Poetry slips through \\ the chaos of academe \\ crafting our pleasure \\ Poetry brings warmth \\ inside cold ivory walls \\ to breathe the real \\ Poetry steps up \\ insists on wearing no shoes \\ and creates research \\ Poetry slides in- \\ side the academic world; \\ we make our beds
}

In the past decade, in expanding academic and literary settings throughout the world, and particularly in faculties of education across North America, poetic inquiry has developed meaningful provocations about scholarship and praxis in the social sciences and humanities. In some of our previous publications (Faulkner, 2009; 2014a; 2014b; Guiney Yallop, 2010a; 2014; in press; Guiney Yallop \& Shields, forthcoming; Wiebe, 2012, in press; Wiebe \& Guiney Yallop, 2010), we paid tribute to our colleagues who have created openings for creative and critical work, and built, and continue to build, strong communities for poetic inquiry by providing venues for presentations and publications of the work of researchers who use this form of inquiry. Before we present our colleagues whose works appear in this special issue of in education, and whose contributions add to the growing conversations and perspectives on poetic inquiry, we feel it is important to acknowledge what we see as communal sites of poetic inquiry, sites we return to for our own nourishment as we continue our work as poetic inquirers.

In October 2013, the Fourth International Symposium on Poetic Inquiry (ISPI) was held in Montreal, Quebec, and was co-hosted by Lynn Butler-Kisber of McGill University, John J. Guiney Yallop from Acadia University, and Mary Stewart from LEARN. These ISPI, as they have come to be known, began when Monica Prendergast, University of Victoria, and Carl Leggo, University of British Columbia, invited colleagues who had published peer-reviewed poetic inquiry to attend an International Symposium on Poetic Inquiry at the University of British Columbia in Vancouver, Canada. It became clear, as the symposium was drawing to a close, that there was a desire to hold another symposium. Two years later, Suzanne Thomas, University of Prince Edward Island, and Ardra Cole, University of Toronto, co-hosted the Second ISPI in Charlottetown, Prince Edward Island; presenters at this, and subsequent symposia, responded to a call for presentations. Following the Second ISPI, the now biannual conference moved across the Atlantic to the United Kingdom and was hosted at Bournemouth University, England, by Kate Galvin and Les Todres. Since that first symposium, two books (Prendergast, Leggo, \& Sameshima, 2009; Thomas, Cole \& Stewart, 2012) and three special 
issue journals (Educational Insights, 13(3), Prendergast, Leggo, \& Sameshima; Learning Landscapes, 4(1), Butler-Kisber \& Stewart; and Creative Approaches to Research, 5(2), Galvin \& Prendergast) have brought together voices and perspectives on poetic inquiry. Two additional books (Galvin \& Prendergast, forthcoming; Butler-Kisber, Guiney Yallop, Stewart, \& Wiebe, forthcoming) are expected in the next couple of years, and another ISPI is being planned by Pauline Sameshima, Alexandra Fidyk, Kedrick James, and Carl Leggo (http://www.poeticinquiry.ca/).

In addition to building relationships with each other through those symposia, the researchers doing this work have reached out to poetic inquirers across national borders and beyond continental boundaries; global conversations are happening with, in, and through this work. This special issue of in education explores our connective educational landscape through the use of poetic inquiry; it expands these conversations by adding new contributions and perspectives, and by inviting us to engage in the conversations to bring our own voices and perspectives to this community.

\section{Question and Answer}

As we introduce this special issue, we also feel that it is important to offer the reader a sense of who we, the co-editors of this special issue, are as poetic inquirers, to make ourselves more present/visible in this publication. Thus, we decided to create an interview-like environment where each of us responded to ten questions we compiled together. We offer these questions and responses as avenues into the ongoing conversations, and we encourage readers to also respond to these questions before, during, and/or after they read through the articles in this in education special issue on poetic inquiry.

\section{What Does Poetic Inquiry Mean to You?}

JJGY: Poetic inquiry is a way in for me. There are other ways in, but for me, I had to reawaken the poet to become a researcher (Guiney Yallop, 2005), or at least, to continue to become the researcher I needed to become in order to do the work I needed to do, that is to explore my own identities and the communities in which those identities were located (Guiney Yallop, 2008).

SF: I consider poetry an excellent way to (re)present data, to analyze and create understanding of human experience, to capture and portray the human condition in a more easily "consumable," powerful, emotionally poignant, and open-ended, non-linear form compared with prose research reports (Faulkner, 2009). Poetry constitutes a way to say things evocatively and to say those things that may not be presented at all.

SW: Poetic inquiry invites me into the in-between space between creative and critical scholarship. Such a space is reflexive and critical, aware of the nexus that is both self and other, both personal and public.

\section{How do you use Poetry in Your Academic Work? What Does Poetic Inquiry Help You Do?}

SF: I use poetic inquiry in/for/as social science research to accomplish three goals: (a) to connect social research and poetry, (b) to effect social change through a focus on the aesthetic, and (c) to use poetry/poetic inquiry as a pedagogical tool. 
JJGY: I use poetic inquiry to help me get up close-up close to the work I am doing. Interestingly, poetic inquiry also helps me step back from my work. I can step back and look at the poem. I can put the poem away for a while. The poem, however, continues to call me closer, to have a closer look. I use poetic inquiry in all of my research, in autoethnography as well as work with participants, with documents, and with memories-my own and the memories of others.

SW: Lately, I've been trying out an idea, thinking that in poetic inquiry there is an interweaving relationship among three ways of being in the world: fierce, tender, and mischievous. Thinking of the various intersections and blends of these habits of mind and heart enriches, for me, those discussions of poetic inquiry that are more methodological. What can be learned from the poet's fierce/mischievous openness to the aesthetic qualities of human experience? Or, how might a poet's tenderness enhance the pursuit of knowing human experience more deeply?

\section{What are the Possibilities of Poetic inquiry?}

JJGY: Poetic inquiry offers possibilities; it doesn't seek them. I am seeking possibilities. I am seeking ways into research, ways to better understand who I am and how I live, or might live, in this world, and what I might be able to offer to others who share this life with me. Poetic inquiry offers me the possibility of intimacy in research, the possibility of connection.

SW: Sometimes I like to think of the impossibilities we pursue in poetic inquiry. Having recently read, Rapport and Hartill's (2012) paper, Crossing Disciplines with Ethnographic Poetic Representation, I admire their undaunted pursuit of the impossibility of investigating the lived experience of holocaust victims. There was a moment in Rapport's ethnographic work when she encountered the question: "What do you know about the Holocaust?" (p. 12). What I hear is How dare you, but also I dare you. It is the taunting voice of the difficult, the impossible, and I suspect that it is this unsilenceable voice that summons Rapport and Hartill's research questions.

SF: Like John, poetic inquiry has enabled me to connect the personal with the academic. In my book of poetry as memoir (Faulkner, 2014b), I use poetic analysis, a technique of using poems as data for qualitative research, to make an explicit connection between poetry and interpersonal relationships by detailing what it means to be a woman in my family and demonstrate the crafting of relationships as vital women's work. This analysis and subsequent representation serve as an exemplar of how poetry offers an explicit demonstration of individuals' needs to poeticize their everyday relational challenges (Faulkner, 2012a, 2012b, 2014a; Pelias, 2011).

\section{Who are some of your Favourite Poets and Why? What Three Poetry Books Have Most Influenced You and Why?}

SF: I am a (feminist) relationship researcher and relational processes are my lexicons. Thus, the three most important books for my development as a poetic inquirer all concern feminism and relationships:

1. Denise Duhamel's Kinky (1997). This book of Barbie poems critiques body image and stunted expectations of girls' and women's lives with fun and snarky commentary.

2. Kim Addonizio's Tell Me (2000). The bold and uncontained analysis of women's desire is stunning. 
3. Frank X. Walker's When Winter Come, The Ascension of York (2008). Walker reminds me that the story behind an official report is often the most interesting.

JJGY: Hmmm. That's a hard one. I have love affairs (at least in my own mind and heart) with poets, mindful and heartful connections with/in their work. Some of those affairs go on for years, even decades, while some have less longevity but are certainly still passionate. Kahlil Gibran has been a long-time favourite, because I read his work when I was a very young man and he moved me to write poetry about my experience. Maya Angelou, I also love because her poetry speaks to my soul; it was a particular honour to be published in the same issue of a journal with Maya Angelou (Angelou, 2010; Guiney Yallop, 2010b). Carl Leggo is another poet who is very dear to me because he plays with language and, in doing so, invites me to play as well.

Books that have influenced me greatly as a poet are Seasonal Bravery by Des Walsh (1980). I recall when it first came out, I was astonished by how beautiful, how accessible, and how sensual poetry could be; I think I developed an immediate crush on Des Walsh. The Prophet by Kahlil Gibran (1982) also had a great influence on me, at about the same time as Des Walsh's work was affecting me so deeply. Like Seasonal Bravery, The Prophet also told me that poetry can be, in fact is, about life. Erosion by E. J. Pratt (1981) is not a book, but a single, very short, poem, one of the most beautiful poems I have ever read. It amazed me that so few words could create so many pictures and evoke such deep emotions. Apparently, I went up in a colleague's esteem when he discovered I had a poem published with E. J. Pratt in the same edited collection (Guiney, 1981).

SW: Billy Collins reminds me to be playful, imaginative. With Billy, I'm invited into musings that are amusing. I've recently reread his (2007) The Trouble with Poetry, and the idea of troubling something continues to prompt me to turn things upside down and inside out. Lydia Davis must be mentioned. Her poem “A Mown Lawn” (2009) led me down a rabbit hole of pursuits so pleasurable even Coleridge would be jealous. Whenever I'm matched against someone holding Milton or Wordsworth, Davis is my trump card. Like John, I will mention Carl Leggo. A quarter century ago, I was in Carl Leggo's class as an undergraduate student. He was a magician then, and his belief that poetry could change the world was so strong that my only response was to roll up my sleeves and get to work. Since then I can hardly count the number of times where I've been the woman at the well and Carl's been Jesus (John 4, 4-30). Sometimes the poem is the person, and it is the nature of the composition that matters most.

\section{What Do Poets Do Better?}

JJGY: Poetry

SF: I am going to quote Norm Denzin (2014): "The poet makes the world visible in new and different ways, in ways ordinary social science writing does not allow. The poet is accessible, visible, and present in the text, in ways that traditional writing forms discourage” (p. 86).

SW: Ha, ha, ha. I'm not going to answer that question.

\section{How Does Poetic Inquiry Intersect With Your Other Work?}

SW: I will answer that question. Poetry is ideally suited for writing oneself into the world, which is why I often situate my poetic inquiry within curriculum studies, particularly Pinar's (2004) notions of currere and complicated conversation. 
SF: For me, poetry can be a method of inquiry, a (re)presentation of qualitative data, and a means of data analysis (for example, Faulkner, Calafell, \& Grimes, 2009; Faulkner \& Nicole, forthcoming; Faulkner \& Ruby, in press).

JJGY: What other work?

\section{What Distinguishes Poetic Inquiry From Other Arts-based Qualitative Research Methods?}

SW: I think it is a sustained and contemplative love of language. Susan Walsh (2012) describes her poetic inquiry process as being present and dwelling with particular artifacts rather than analyzing or interpreting them (p. 273). She says this involves listening to the text, asking what it wants her to do (p. 274). Eisner (2005) writes that "As we learn to think within the medium we choose to use, we also become more able to raise questions that the media themselves suggest" (p. 181). It seems to me that each medium, each form, has within it a slightly different kind of thinking, and that this thinking-which provides direction for how to proceed with representing the knowledge-does not become apparent without sustained contemplation.

SF: Poetry embodies experience to show truths that are not usually evident. For example, our deeply ingrained ideas about gender and culture and class and race, the seemingly natural ways of being are easier to unravel in verse (e.g., Faulkner, Calafell, \& Grimes, 2009).

JJGY: For me, it's like the Matryoshka dolls; poetic inquiry goes further inside to the hidden, or waiting, treasure that the first, or second, glance does not give access to.

\section{Where are you currently in your growth as a poetic inquirer?}

SF: I am using poetry and poetic inquiry as a pedagogical tool in my teaching of research methods and relational communication. This kind of writing speaks more to students than traditional social science writing. The language of poetry, when properly absorbed, becomes part of our private vocabulary, our way of moving through the world. Poetry matters, and without it we can live only partially, not fully conscious of the possibilities (emotional and intellectual) that life affords (Parini, 2008, p. xiv). Poetry resonates with readers, and audiences experience poems as "evocative mediators" of painful relational experiences; they recognize and tell their own stories (Todres \& Galvin, 2008, p. 571).

JJGY: I woke up the poet to become a researcher. I am reminding myself to stay awake and to keep waking up. Academic life, if one is not careful, can put one to sleep; it can kill (or dull) the spirit by constantly pulling it away from itself. I love my work. I love being an academic. When I forget to love, I forget to write. When I forget to love, I fall asleep-a dreamless sleep. When I love, I remember to write. When I love, I awaken and I keep waking up. When I love and sleep, I dream in poetry. Lorri Neilsen (in conversation) once reminded me to give primary attention to the art. I haven't always followed that wise advice. When I haven't, my work has suffered, and I have as well; so has everyone around me. When I pay attention to the art, to the poetry, all is right, or being made right, with the world, at least with my world and those I share it with-our world.

SW: I'm learning to take pleasure in the text. Leggo's love of Barthes has influenced me along these lines. However, the text is not just words on the page; it is my life text, our life texts, together, and the textual lands of our locations in space and time. In my journal this morning I 
wrote that I write poetry as a practice of savouring life, to appreciate what is given by taking pleasure in it.

\section{This Issue: Practices of Poetic Inquiry}

Now we turn to the authors whose works appear in this in education special issue on poetic inquiry to, as Sean noted above, "appreciate what is given by taking pleasure in it." We acknowledge with gratitude, and with pleasure, the work of these authors and their generosity in sharing their writing in this space. We also acknowledge the thoughtful and supportive feedback given by the peer reviewers who reviewed the articles for this special issue. Finally, we thank Patrick Lewis for his enthusiasm in responding so affirmatively to the suggestion of doing an in education special issue on poetic inquiry, and we thank Shuana Niessen for guiding us through the processes of building a special issue of this wonderful journal.

In "Poetic Inquiry and Its Lyrical Potentials for Research,” Nilofar Shidmehr reviews early Western philosophy to show how and why the lyrical was excluded from serious scholarship. She then makes the case for why we should re-include it in social and educational research, pointing out how poetry's attentiveness, openness to mystery, and experimentation in language can help us imagine alternative ways of being and thinking.

Alexandra Fidyk, Lorri Neilsen Glenn, and Merle Nudelman, in "The Radiance of the Small," introduce us to small creatures with whom we share this planet in order to help us better understand big realities; each author offers us a personal account of connection and transformation. From the east and west coasts of Canada, and from the past and the present, Heather McLeod and Gisela Ruebsaat, in their poetically rendered duoethnography, “' The Receiver No Longer Holds the Sound': Parents, Poetry, and the Voices We Create in the World,” take us into the relationships they hold with their parents, which they continue to explore after the deaths of those parents. In "Poetic Inquiry as Visiting: Stories of Men," Jodi Marie Latremouille weaves together the scholarly traditions of curriculum, life writing, and poetic inquiry. Critical of a kind of writing that wraps up findings with a few analytical reflections, Latremouille asks how, as educators, we might understand pedagogy in a way that respects relationality. Reminding us of the wisdom that words live in us and with us, she calls us to sit with our stories, to visit with them, to recognize their relatedness to who we are. In their article, “You Don’t Know Me: Adolescent Identity Development Through Poetry Performance,” Janette Michelle Hughes, Laura Jane Morrison, and Cornelia Hoogland help us get to know their adolescent participants by sharing the identities voiced throughout their research; we gain a deeper insight into a world changing. In "Ekphrastic Poetics: Fostering a Curriculum of Ecological Awareness Through Poetic Inquiry,” Andrejs Kulnieks and Kelly Young use visual art and poetry to deepen their own ecological awareness and to encourage the development of such an awareness in the teacher education students they work with. Carli Molinar, in "Life and Mortality: A Teacher's Awakening," poetically represents the experiences of teaching in a setting with a terminally ill child, interspersing portions of her experiences with those of a dying nine-year old boy to remind readers that education is more than just formalized curriculum. In "Liminal Lives: Navigating the Spaces Between (Poet and Scholar)," Cynthia L. Clarke espouses the need to understand how narrative grounds our educational experiences. Through examples of personal writing practices, Clarke shows us how reading and writing poetry broadens our conceptions of identity and educational practice. Kimberly Anne Holmes' meditation on

mindfulness in "Synthesis: A Poetic Exploration of the Integral Model Investigating the 
Interconnected Strands of Mindfulness in Our Educational Landscape” highlights the importance of being present and of recognizing the importance of free space in education. Holmes weaves personal experience and research on curriculum and learning into a tapestry of teacher and student expression. Karla Jessen Williamson, in "Uumasuusivissuaq: Spirit and Indigenous Writing," shows how using poetic forms can decolonize written academic "knowledge" of indigenous peoples. In her article, she demonstrates the use of poetry and writing practices as a tool to help indigenous scholars decolonize the academy. In "Performing Embodied Pedagogy: Listening to the Small Talk of My Injured Back," Lorna Louise Ramsay troubles her preperformance postures as an educator/musician, asking how self-perception can be interpreted and reinterpreted to express the unspoken and visceral. Her inquiry is a poetic sharing of the interpretive and aesthetic work she does with teacher candidates' corporeal histories, and she invites us to consider how the injured body can facilitate a pedagogy of nonjudgment, eliciting feelings of belonging and supporting vulnerable expression. William A. Welton and Daniela Elza, in "The Many Paths to Sophia: Toward a Deeper Philosophical Appreciation of Poetry," disrupt assumptions. By creating and weaving paths, the authors invite us to travel to deeper understandings of work that has previously been separated.

This special issue of in education concludes with two book reviews: Vanessa Tse, University of Victoria takes us inside Poetic Inquiry: Vibrant Voices in the Social Sciences and Susan Manning, Mount Saint Vincent University, explores The Art of Poetic Inquiry. Both reviewers bring further vibrancy and artful perspectives to their (and our) readings of those texts. They remind us of the importance of returning to, or beginning with, as we continue to grow a community of poetic inquirers and a landscape of poetic inquiry.

We hope that readers of this special issue will find as much pleasure and learning in it as we found it collaborating as guest editors to bring it together. 


\section{References}

Addonizio, K. (2000). Tell me. Rochester, NY: BOA Editions, Ltd.

Angleou, M. (2010). Poetry is the human heart speaking in its own melody. LEARNing Landscapes, 4(1), 15-19. Retrieve from http://www.learninglandscapes.ca/images/documents/ll-no7-v-final-lr.pdf

Collins, B. (2007). The trouble with poetry: And other poems. New York, NY: Random House.

Davis, L. (2009). A mown lawn. In Davis, L.(Ed.), The collected stories of Lydia Davis. New York, NY: Farrar, Straus and Giroux.

Denzin, N. K. (2014). Interpretive autoethnography ( $2^{\text {nd }}$ ed.). Thousand Oaks, CA: Sage.

Duhamel, D. (1997). Kinky. Alexandria, VA: Orchises Press.

Eisner, E. (2005). Reimagining schools: The selected works of Elliot W. Eisner. New York, NY: Routledge.

Faulkner, S. L. (2009). Poetry as method: Reporting research through verse. Walnut Creek, CA: Left Coast Press.

Faulkner, S. L. (2012a). Frogging it: A poetic analysis of relationship dissolution. Qualitative Research in Education, 1(2), 202-227. doi:10.4471.qre.2012.08

Faulkner, S. L. (2012b). That baby will cost you: An intended ambivalent pregnancy. Qualitative Inquiry, 18(4), 333-340.

Faulkner, S. L. (2014a). Bad Mom(my) Litany: Spanking Cultural Myths of Middle-Class Motherhood. Cultural Studies <=> Critical Methodologies, 14(2), 138-146. doi:10.1177/1532708613512270

Faulkner, S. L. (2014b). Family stories, poetry, and women's work: Knit four, frog one. Rotterdam, NL: Sense Publishers.

Faulkner, S. L., Calafell, B. M., \& Grimes, D. S. (2009). Hello Kitty goes to college: Poems about harassment in the academy. In M. Prendergast, C. Leggo, \& P. Sameshima (Eds.), Poetic inquiry: Vibrant voices in the social sciences (pp. 187-208). Rotterdam, NL: Sense Publishers.

Faulkner, S. L., \& Nicole, C. (forthcoming). Embodied poetics in mother poetry: Dialectics and discourses of mothering. In K. Galvin \& M. Prendergast (Eds.), Poetic inquiry II: Seeing, understanding, caring: Using poetry as and for inquiry. Rotterdam, NL: Sense Publishers.

Faulkner, S. L., \& Ruby, P. D. (in press). Feminist identity in romantic relationships: A relational dialectics analysis of email discourse through the use of collaborative found poetry. Women's Studies in Communication.

Galvin, K. T., \& Prendergast, M. (forthcoming). Poetic inquiry II: Seeing, understanding, caring: Using poetry as and for inquiry. Rotterdam, NL: Sense Publishers. 
Gibran, K. (1982). The prophet. New York, NY: Alfred A. Knopf.

Guiney, J. J. (1981). P. Cove. In E. H. King (Ed.), Choice poems from the Newfoundland Quarterly 1901-1981 (p. 14). St. John’s, ND: Harry Cuff Publications.

Guiney Yallop, J. J. (2005). Exploring an emotional landscape: Becoming a researcher by reawakening the poet. Brock Education, 14(2), 132-144.

Guiney Yallop, J. J. (2008). OUT of place: A poetic journey through the emotional landscape of a gay person's identities within/without communities. Unpublished doctoral dissertation. University of Western Ontario, London, ON.

Guiney Yallop, J. J. (2010a). Of place and memory: A poetic journey. Halifax, NS: Backalong Books.

Guiney Yallop, J. J. (2010b). Through the words of a poet: Experiencing a writing journey. LEARNing Landscapes, 4(1), 189-210. Retrieve from http://learninglandscapes.ca/images/documents/ll-no7/jigyallop.pdf

Guiney Yallop, J. J. (2014). What if I don't get it right? In A. D. Reid, E. P. Hart, \& M. A. Peters (Eds.), A companion to research in education (pp. 555-558). Netherlands: Springer.

Guiney Yallop, J. J. (in press). Finding grandma: Memories, stories, gifts. K. Galvin \& M. Prendergast. (Eds.). Poetic inquiry II: Seeing, understanding, caring: Using poetry as and for inquiry. Rotterdam, NL: Sense Publishers.

Guiney Yallop, J. J., \& Shields, C. (forthcoming). The poetics of relationship: Thinking through personal pedagogy across time using narrative inquiry and poetic inquiry. In N. Ng-AFook, G. Reis, \& A. Ibrahim (Eds.), Provoking curriculum studies: Strong poetry and the arts of the possible in education. New York, NY: Routledge.

Parini, J. (2008). Why poetry matters. New Haven, CT: Yale University Press.

Pelias, R. J. (2011). Leaning: A poetics of personal relations. Walnut Creek, CA: Left Coast Press.

Pinar, W. F. (2004). What is curriculum theory. Mahwah, NJ: Erlbaum.

Pratt, E. J. (1981). Erosion. In E. H. King (Ed.). Choice Poems from the Newfoundland Quarterly 1901-1981 (p. 75). St. John’s, ND: Harry Cuff Publications.

Prendergast, M., Leggo, C., \& Sameshima, P. (2009). Poetic inquiry: Vibrant voices in the social sciences. Rotterdam, NL: Sense Publishers.

Rapport, F., \& Hartill, G. (2012). Crossing disciplines with ethnographic poetic representation. Creative Approaches to Research, 5(2), 11-25.

Thomas, S., Cole, A., \& Stewart, S. (Eds.). (2012). The art of poetic inquiry. Big Tancook Island, NS: Backalong.

Todres, L., \& Galvin, K. T. (2008). Embodied interpretation: A novel way of evocatively representing meanings in phenomenological research. Qualitative Research, 8(5), 568-583. doi:10.1177/1468794108094866 
Thomas, S. Cole, A., \& Stewart, S. (Eds.). (2012). The art of poetic inquiry. Halifax, NS: Backalong Books.

Walker, F. X. (2008). When winter come: The ascension of York. Lexington, KY: University Press of Kentucky.

Walsh, D. (1980). Seasonal bravery. Breakwater.

Walsh, S. (2012). Contemplation, artful writing: Research with internationally educated female teachers. Qualitative Inquiry, 18(3), 273-285. doi: 10.1177/1077800411431553

Wiebe, S. (2012). The poet and the pea: Poems staged in Menippean dialogue to explore empathy in education. Creative Approaches to Research, 5(2), 34-47.

Wiebe, S. (in press). The strong poets as unconscious mentor metaphors. In N. Ng-A-Fook, G. Reis, \& A. Ibrahim (Eds.), Provoking curriculum studies: Strong poetry and the arts of the possible in education, New York, NY: Routledge.

Wiebe, S., \& Guiney Yallop, J. J. (2010). Ways of being in teaching: Conversing paths to meaning. Canadian Journal of Education, 33(1), 177-198. Retrieve from http://www.cssescee.ca/CJE/Articles/FullText/CJE33-1/CJE33-1-WiebeYallop.pdf 